\title{
Expression of Angiogenic Regulators, VEGF and Leptin, Is Regulated by the EGF/PI3K/STAT3 Pathway in Colorectal Cancer Cells
}

\author{
SANDRA CASCIO,' RITA FERLA, ${ }^{1,2}$ ALECO D'ANDREA,' ALDO GERBINO, ${ }^{3}$ \\ VIVIANA BAZAN,' EVA SURMACZ, ${ }^{2}$ AND ANTONIO RUSSO'* \\ 'Department of Surgical and Oncological Sciences, Section of Medical Oncology, Università di Palermo, Palermo, Italy \\ ${ }^{2}$ Sbarro Institute for Cancer Research and Molecular Medicine, Temple University, Philadelphia, Pennsylvania \\ ${ }^{3}$ Histological and Embriological Section, Department of Experimental Medicine, Institute of Pathology, \\ Università di Palermo, Palermo, Italy
}

Both leptin and vascular endothelial growth factor (VEGF) are growth and angiogenic cytokines that are upregulated in different types of cancer and have been implicated in neoplastic progression. Here we investigated the molecular mechanism by which leptin and VEGF expression are regulated in colon cancer by epidermal growth factor (EGF). In colon cancer cell line HT-29, EGF induced the binding of signal transducer and activator transcription 3 (STAT3) to STAT3 consensus motifs within the VEGF and leptin promoters and stimulated leptin and VEGF mRNA and protein synthesis. All these EGF effects were significantly blocked when HT-29 cells were treated with an inhibitor of the phosphoinositide 3-kinase (PI3K) pathway, LY294002, or with small interfering RNA (siRNA) targeting STAT3. Thus, our study identified the EGF/PI3K/STAT3 signaling as an essential pathway regulating VEGF and leptin expression in EGF-responsive colon cancer cells. This suggests that STAT3 pathways might constitute attractive pharmaceutical targets in colon cancer patients where antiEGF receptor drugs are ineffective.

J. Cell. Physiol. 221: 189-194, 2009. (C) 2009 Wiley-Liss, Inc.

Neoangiogenesis is a critical step for tumor growth and metastatic spread (Folkman, 197I). New blood vessels formation depends on the balance between positive and negative regulators and is induced when factors that promote angiogenesis are upregulated or those that inhibit angiogenesis are down-regulated (Ferrara and Kerbel, 2005).

Vascular endothelial growth factor (VEGF) plays a major role in tumor angiogenesis and its expression is inversely correlated with patient survival in many human cancers, including colon carcinomas (Logan-Collins et al., 2008; Zafirellis et al., 2008). VEGF expression is regulated by various signaling pathways induced by external stimuli (e.g., hypoxia, hormones, cytokines) and may depend on the cellular context (e.g., the presence of activated oncogenes) (Xu et al., 2005). Epidermal growth factor (EGF) receptor (EGFR) signaling pathway is commonly activated in colorectal cancer and has been investigated as a target for cancer therapy (Mendelsohn and Baselga, 2000). After ligand (EGF, transforming growth factor) binding to EGFR, a cascade of downstream signaling is activated, including activation of the Ras-MAP kinase and phosphoinositide 3-kinase (PI3K)/Akt pathways (Mendelsohn and Baselga, 2000). Moreover, in several cell lines, EGF as well as abnormal activation of EGFR signaling pathways induces VEGF expression (Maity et al., 2000; Zhong et al., 2000). Conversely, EGFR inhibition can decrease VEGF expression, and consequently angiogenesis, in many tumor types (Ciardiello and Tortora, 200I; Pore et al., 2006).

A less well-known factor with a strong neoangiogenic activity is leptin (Cao et al., 200 I; Anagnostoulis et al., 2008). Leptin is a pleiotropic hormone whose major role is to regulate food intake and energy balance via hypothalamic effects. Leptin also affects many peripheral organs, behaving as a mitogen, survival factor, metabolic regulator, or angiogenic factor (Wauters et al., 2000; Cao et al., 200I; Misztal-Dethloff et al., 2004; Gonzalez et al., 2006). Furthermore, there is evidence that leptin promotes neoplastic processes in different cell types (Garofalo et al., 2006; Housa et al., 2006). In colorectal cancer, leptin can promote proliferation and invasiveness, and inhibit apoptosis (Attoub et al., 2000; Aparicio et al., 2004; Amemori et al., 2007; Jaffe and Schwartz, 2008). In addition, human colorectal cancers have been shown to overexpress leptin as well the leptin receptor (ObR) (Koda et al., 2007).

The VEGF and leptin gene promoters contain several regulatory motif as ERE, CRE, SP-I, AP-2, HRE, and SRE (STAT3-responsive element) (Finkenzeller et al., 1997; Mason et al., 1998; Brenneisen et al., 2003). STAT3 is a transcription factor activated through phosphorylation on a conserved tyrosine residue (Tyr705), leading to STAT3 dimerization, nuclear translocation and DNA binding to specific consensus sequence TT $\left(\mathrm{N}_{4 / 5}\right)$ AA (Seidel et al., 1995; Frank, 2007). STAT3 has been identified as a major regulator of VEGF expression in glioblastoma and prostate cancer (Niu et al., 2002; Wei et al., 2003). VEGF induction by various oncogenic growth stimuli,

Cascio Sandra and Ferla Rita contributed equally to this work.

*Correspondence to: Antonio Russo, Department of Surgical and Oncological Sciences, Section of Medical Oncology, Università di Palermo, via del Vespro 127, 90127 Palermo, Italy.

E-mail: lab-oncobiologia@usa.net

Received 16 April 2009; Accepted 28 April 2009

Published online in Wiley InterScience (www.interscience.wiley.com.), 2 June 2009. DOI: $10.1002 / j c p .21843$ 
including IL-6, c-src, Her2/Neu can be abrogated by interruption of STAT3 signaling with dominant-negative STAT3 protein or STAT3 antisense nucleotide (Wei et al., 2003; Xu et al., 2005).

Recently data demonstrated that STAT3 is involved in colorectal cancer cells growth, survival, invasion, and migration (Klampfer, 2008), through upregulation of various genes, including VEGF (Xiong et al., 2008). However, the role of STAT3 in VEGF or leptin expression in colorectal cancer has never been assessed.

Because the growth of colorectal cancer cells can be regulated by the EGF/STAT3 pathway (Alvarez et al., 2006; Vigneron et al., 2008), we tested if this pathway can be involved in the activation of two angiogenic factors, VEGF and leptin. Here we demonstrated that in colorectal cancer cell line HT-29, EGF-induced leptin and VEGF expression is mediated by the recruitment of STAT3 to SRE motif in both VEGF and leptin gene promoters. EGF effects on VEGF and leptin expression were significantly blocked with small interfering RNA (siRNA) targeting STAT3.

Materials and Methods

Cell culture and treatments

HT-29 cells were grown in GIBCO ${ }^{\text {TM }}$ Leibovitz's L- 15 Medium (Invitrogen, Carlsbad, CA) supplemented with 10\% fetal bovine serum (FBS), $100 \mathrm{U} / \mathrm{mL}$ penicillin, and $50 \mu \mathrm{g} / \mathrm{mL}$ streptomycin. A total of $70 \%$ confluent cells were synchronized in serum-free medium (SFM) for $24 \mathrm{~h}$ and then stimulated with $10 \mathrm{ng} / \mathrm{ml}$ EGF (R\&D Systems, Minneapolis, MN) for $24 \mathrm{~h}$, with or without a $2 \mathrm{~h}$ pre-treatment of PI3K inhibitor LY294002 (Calbiochem, San Diego, CA) at $50 \mu \mathrm{M}$.

\section{Quantitative real-time-PCR (qRT-PCR)}

HT-29 cells were treated, as described above, or left untreated. Total cellular RNA was isolated using the RNeasy Mini Kit (Qiagen, Inc., Valencia, CA). A total of $5 \mu \mathrm{g}$ of RNA was reverse transcribed using the High-Capacity cDNA Archive (Applied Biosystems,

Foster City, CA) according to the manufacturer's protocol. Five microliters of the RT products were used to amplify leptin and VEGF sequences using respectively the $\mathrm{Hs} 00$ I74877_m I Lep and the Hs00900054_ml VEGF TaqMan Kit (Applied Biosystems), following vendor's instructions. To normalize qRT-PCR reactions, parallel reactions were run on each sample for cyclophilin $A$. Changes in the target mRNA content relative to cyclophilin A mRNA were determined using a comparative CT method to calculate changes in CT, and ultimately fold and percent change. An average CT value for each RNA was obtained for replicate reactions.

\section{Leptin and VEGF detection by ELISA}

A total of $3.6 \times 10^{7}$ HT-29 cells (or $1.8 \times 10^{7}$ for STAT3 siRNA) were treated, as above described. Secreted VEGF and leptin were measured in cell culture media using Human Quantikine ELISA Kits (R\&D Systems) with the lowest detection limit of $5 \mathrm{pg} / \mathrm{ml}$ for VEGF and $7.8 \mathrm{pg} / \mathrm{ml}$ for leptin, intra-assay precision of $<8.8 \%$ (VEGF) and $<4.9 \%$ (leptin), and inter-assay precision $<9.2 \%$ (VEGF) and $<8.2 \%$ (leptin). All points were done in triplicate and the experiments were repeated three times. All leptin and VEGF concentrations were within the range of curve standard. Linear regression analysis was performed to create the curve standard.

\section{Western blotting (WB)}

Cytoplasmic and nuclear protein extraction was performed using NE-PER Extraction Reagents (Pierce Biotechnology, Inc.,

Rockford, IL). The expression of STAT3 was analyzed in I $20 \mu \mathrm{g}$ of cytoplasmic or nuclear cell lysates. The following antibodies were used for WB: anti-STAT3 (C-20 X), anti-C23 (MS-3), and
anti-GAPDH (8C2). All above antibody were purchased from Santa Cruz (Santa Cruz Biotechnology, Santa Cruz, CA). Nuclear marker nucleolin and cytoplasmic marker GAPDH were used as loading controls.

\section{Chromatin immunoprecipitation (ChIP)}

ChIP was performed using the Chromatin Immunoprecipitation Assay kit (Upstate, Temecula, CA), according to manufacturer's instructions. Soluble chromatin was immunoprecipitated with STAT3 (C-20) pAb (Santa Cruz Biotechnology). The presence of leptin and VEGF promoter domains containing STAT3 motifs in immunoprecipitated DNA was identified by PCR using the following primers: for leptin (region from - I892 to - 1403) forward 5'-TTG TGG TCA GAC CAG TTT TCT-3', reverse 5'-GTT TGG TAA TGC CCA AAA GCT-3', for VEGF (region - I04I from to -750) forward 5'-CAG GAA CAA GGG CCT CTG TCT-3', reverse 5'-TGT CCC TCT GAC AAT GTG CCA TC-3'. The PCR conditions for leptin region were: I min at $94^{\circ} \mathrm{C}$, I min at $60^{\circ} \mathrm{C}$, I min at $72^{\circ} \mathrm{C}$; for VEGF region: I min $94^{\circ} \mathrm{C}$, I min at $64^{\circ} \mathrm{C}$, I min at $72^{\circ} \mathrm{C}$. The amplification of these regions was analyzed after PCR 35 cycles.

\section{Knockdown of STAT3 using small interfering RNA (siRNA)}

STAT3 knockdowns were achieved using siRNAs (Dharmacon, Inc., Lafayette, CO), according to manufacturer's instructions. Twenty-four hours following transfection, the cells were placed in SFM for $24 \mathrm{~h}$, then stimulated with EGF $10 \mathrm{ng} / \mathrm{ml}$ for $24 \mathrm{~h}$ or left untreated. Non-specific siRNA (Dharmacon, Inc.) was used as a negative control.

\section{Results}

\section{EGF upregulates VEGF and leptin expression}

Since it is known that EGF regulates tumor-associated angiogenesis, we assessed EGF effects on the expression of VEGF and leptin. First, we measured the effects of EGF on VEGF and leptin mRNA levels. The treatment of HT-29 cells with EGF for $24 \mathrm{~h}$ induced VEGF mRNA production by I.4-fold (Fig. Ia). Similarly, EGF stimulated leptin mRNA expression by 2.7 -fold at $24 \mathrm{~h}$ relative to untreated cells (Fig. Ib). In parallel, EGF increased the levels of secreted VEGF and leptin by 2.6- and I.7-fold, respectively (Fig. Ic,d). These results suggested that EGF upregulates VEGF and leptin at mRNA and protein levels.

\section{EGF-induced STAT3 recruitment to VEGF and leptin promoters}

Analysis of the VEGF promoter revealed a putative binding site for STAT3 at the -848 position (Niu et al., 2002). We also identified two binding sites for STAT3 within the leptin promoter at $-I 7 \mid 5$ and at $-I 500$ positions. Consequently, we investigated whether STAT3 could mediate EGF effects on VEGF and leptin expression in HT-29 colon cancer cell line.

We first examined the abundance of nuclear STAT3 in cells treated with EGF (Fig. 2a). In untreated cells, STAT3 was expressed in the nucleus at relatively low levels, while following EGF stimulation, nuclear accumulation of STAT3 was significantly increased ( 2.5 -fold, relative to untreated cells); at the same time, the cytoplasmic STAT3 levels remained unchanged. Next, we assessed STAT3 binding to specific motifs in the VEGF and leptin promoters (Fig. 2b). Our result suggested that EGF increased STAT3 recruitment to both VEGF and leptin promoters by three fold.

\section{Silencing of STAT3 expression reduces VEGF and leptin induction by EGF}

To verify STAT3 involvement in EGF-induced VEGF and leptin mRNA production, we silenced STAT3 expression using RNA interference. The specific STAT3 siRNA down-regulated basal 
a

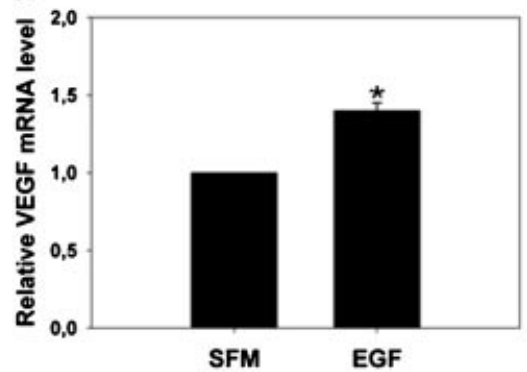

b

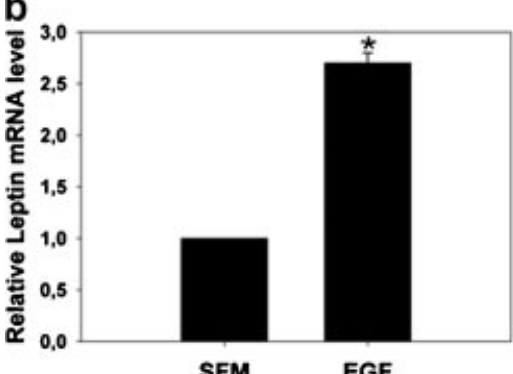

C

\begin{tabular}{|l|c|c|}
\hline Treatment & SFM & ECF 24h. \\
\hline $\begin{array}{l}\text { Vegf } \\
\text { (pg/mi) }\end{array}$ & $168 \pm 18$ & $443 \pm 60$ \\
\hline
\end{tabular}

d

\begin{tabular}{|l|c|c|}
\hline Treatment & SFM & EGF 24h. \\
\hline $\begin{array}{l}\text { Leptin } \\
\text { (pg/mI) }\end{array}$ & $55 \pm 8$ & $91 \pm 6$ \\
\hline
\end{tabular}

Fig. I. Leptin and VEGF mRNA and protein expression increases in response to EGF stimulation. a,b: The abundance of VEGF and leptin mRNA were studied with QRT-PCR. HT-29 cells were synchronized in SFM for $24 \mathrm{~h}$ and then treated with $10 \mathrm{ng} / \mathrm{ml}$ EGF for $24 \mathrm{~h}$ or left untreated.

To normalize $\mathrm{qRT}$-PCR reactions, parallel reactions were run on each sample for cyclophilin $A$. The graphs represent increase of VEGF and leptin mRNA relative to SFM \pm SD. ${ }^{*}, P<0.05$, control versus EGF. c,d: The abundance of VEGF and leptin proteins were determined by ELISA assay. A total of $3.6 \times 10^{7} \mathrm{HT}-29$ cells were treated as previously described.

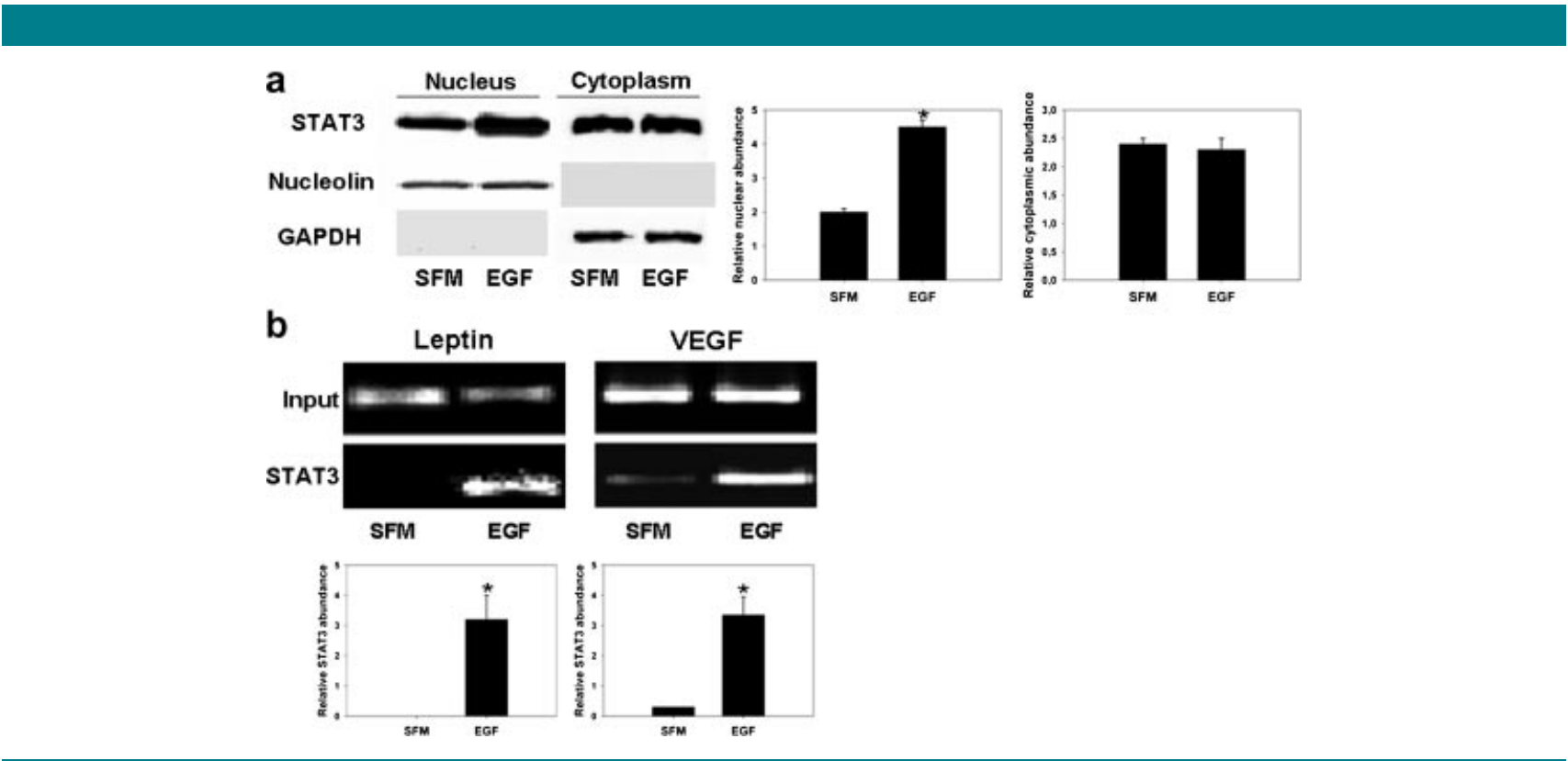

Fig. 2. EGF increases nuclear STAT-3 level and induces loading on the VEGF and leptin promoters. a: HT-29 cells at $70 \%$ confluence were synchronized in serum-free medium (SFM) for $24 \mathrm{~h}$ and then stimulated with $10 \mathrm{ng} / \mathrm{mI} \mathrm{EGF}$ for $24 \mathrm{~h}$. The expression of STAT3 was assessed by WB of I $00 \mu \mathrm{g}$ cytoplasmic and I $20 \mu \mathrm{g}$ nuclear proteins using specific Abs, as described in Material and Methods Section. Graphs represent relative STAT3 expression level normalized to nuclear marker nucleolin and cytoplasmic marker GAPDH; Columns, mean; bars, SD; ${ }^{*}$, P < 0.05 basal versus EGF. b: The binding of STAT-3 on both leptin and VEGF promoters was assessed by ChIP as described in Material and Methods Section. The graphs represent the abundance of STAT3 on VEGF and leptin promoters under different conditions \pm SD; ${ }^{*}, P<0.05$ basal versus EGF-treated Columns, mean; bars, SD. 
STAT3 protein levels by $90 \%$, whereas unrelated siRNA had no effects on this protein (Fig. 3a). STAT3 knockdown reduced by $16 \%$ and $48 \%$ EGF-induced VEGF and leptin mRNA levels respectively as well as down-regulated basal levels of both factors (Fig. 3b). Similarly, STAT3 siRNA reduced EGF-induced secreted VEGF and leptin proteins by $35 \%$ and $25 \%$, respectively (Fig. 3c).

PI3K pathway is involved in EGF-dependent VEGF and leptin expression

The PI3K pathway can regulate VEGF and leptin expression in different cancer cell lines (Maity et al., 2000; Pore et al., 2003; Saxena et al., 2007). Using LY294002 inhibitor, we investigated whether this pathway is required for VEGF and leptin transcriptional regulation in HT-29 cells (Fig. 4c). Inhibition of the PI-3K pathway down-regulated EGF-dependent VEGF and leptin mRNA by $20 \%$, LY294002 also blocked basal level of VEGF mRNA by $70 \%$, whereas basal level of leptin was not affected (Fig. 4c).

Next, we studied whether inhibition of PI3K can affect EGF-induced recruitment of STAT3 to the VEGF and leptin promoters. First, we found that nuclear accumulation of STAT3 was inhibited by $30 \%$ under LY294002 treatment (Fig. 4a). This was followed by reduced EGF-dependent binding of STAT3 to the VEGF and leptin promoters by $30 \%$ and $50 \%$, respectively (Fig. 4b).

\section{Discussion}

Angiogenesis is an essential process for the growth of primary tumor and metastasis formation and VEGF is a recognized critical factor involved in this process (Folkman, 197I). Tumor cells may produce VEGF in response to stimuli, such as cytokines and growth factors, such as EGF, or under hypoxic conditions. Angiogenesis might also be induced by leptin, directly, or indirectly through upregulation of VEGF (Cao et al., 200I; Misztal-Dethloff et al., 2004; Suganami et al., 2004; Anagnostoulis et al., 2008). Here we studied the molecular mechanism by which EGF can promote angiogenesis in colorectal cancer cells, focusing on EGF-dependent activation of pro-angiogenic factors, VEGF and leptin.

We found that in HT-29 colon cancer cell lines, VEGF and leptin levels were upregulated under EGF stimulation. Using qRT-PCR and ELISA assays, we documented increased a
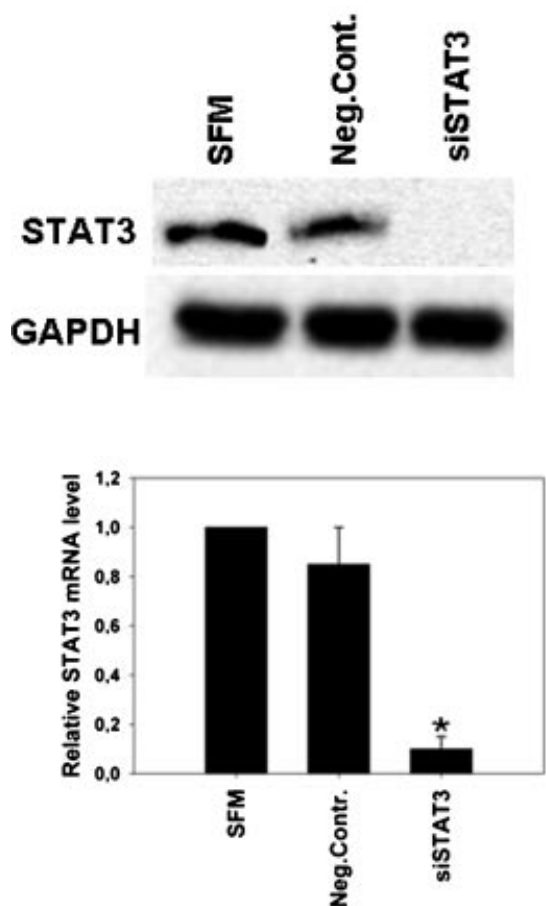

C

\begin{tabular}{|l|c|c|c|c|c|}
\hline Theatent & SFul & negcontr. & siSTAT3 & EGF 24h. & siSTAT3+EGF 24h. \\
\hline $\begin{array}{l}\text { Vegf } \\
\text { (pgin) }\end{array}$ & $85 \pm 10$ & $90 \pm 8$ & $62 \pm 4$ & $220 \pm 30$ & $144 \pm 10$ \\
\hline $\begin{array}{l}\text { Leptin } \\
\text { (pginl) }\end{array}$ & $25 \pm 2$ & $27 \pm 3$ & $15 \pm 4$ & $48 \pm 4$ & $36 \pm 3$ \\
\hline
\end{tabular}

Fig. 3. Knockdown of STAT3 reduces VEGF and leptin expression. a: The expression of STAT3 was determined by WB. Stat 3 knockdowns were achieved using siRNAs as described in Material and Methods Section. After $24 \mathrm{~h}$ from transfection, cells were placed in SFM for $24 \mathrm{~h}$ then stimulated with EGF $10 \mathrm{ng} / \mathrm{ml}$ for $24 \mathrm{~h}$ or left untreated. Non-specific siRNA was used as a negative control. Columns, mean; bars, SD; ${ }^{*}, P<0.05$ SFM versus treated cells. b: The expression of VEGF and leptin mRNA in STAT3 siRNA transfectants treated for $24 \mathrm{~h}$ with EGF or left untreated was studied by qRT-PCR. c: A total of $1.8 \times 10^{7}$ cells were treated as described above. The abundance of secreted leptin and VEGF (pg/ml) in conditioned medium was determined by ELISA. Columns, mean; bars, SD; ${ }^{*}$ or ${ }^{* *}, P<0.05$ basal versus siSTAT3 trasfectant or EGF versus EGF + siSTAT3 trasfectant. 

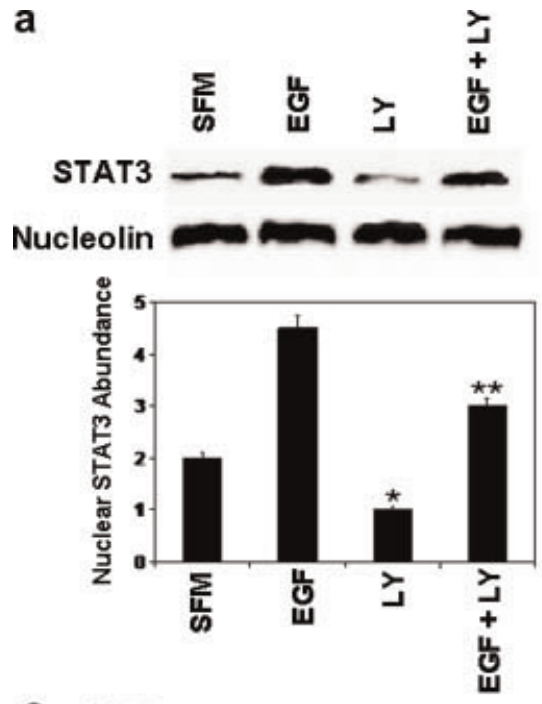

C

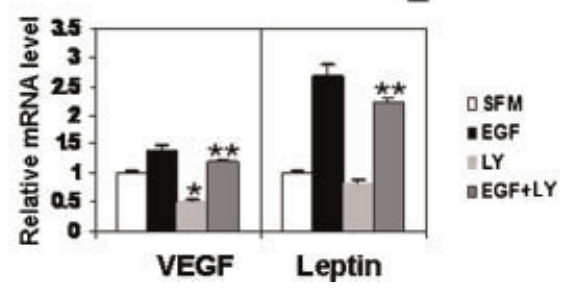

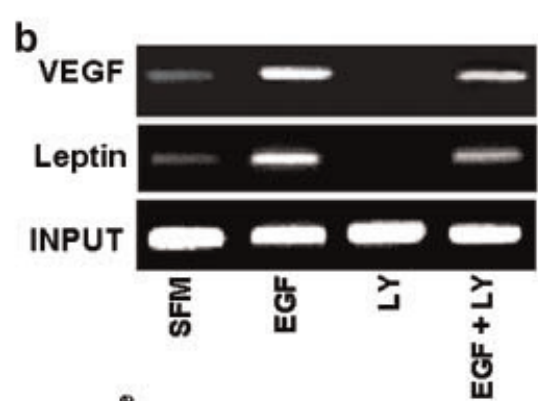

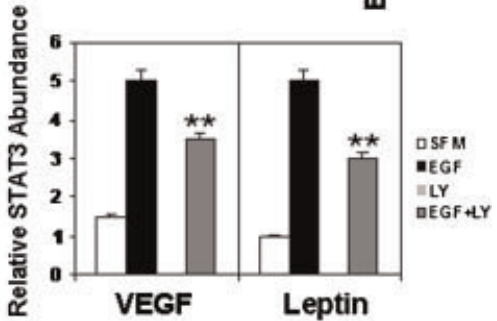

Fig. 4. EGF-induced VEGF and leptin expression is mediated by PI3K. a: HT-29 cells were treated for $24 \mathrm{~h}$ with $10 \mathrm{nM}$ EGF for $24 \mathrm{~h}$ and/or $50 \mu \mathrm{M}$ LY294002. The nuclear abundance of STAT3 was assessed by WB. b: The binding of STAT3 to VEGF and leptin promoter was determined by ChIP as described in material and Methods Section. c: The abundance of VEGF and leptin mRNA was studied with qRT-PCR in HT-29 cells untreated or treated with EGF, and/or LY294002. Columns, mean; bars, SD; ${ }^{*}$ or ${ }^{* *}, P<0.05$ basal versus LY-treated or EGF versus EGF + LY-treated.

expression of both factors at mRNA and protein level. These data are in agreement with the observation that in glioblastoma and prostate cancer cells, EGF can induce VEGF expression (Maity et al., 2000; Zhong et al., 2000). However, direct mechanistic link between EGF and VEGF in colon cancer cells has not been described until now. Moreover, to our knowledge, our data provide the first mechanistic evidence on the role of EGF in the control of leptin expression in cancer cells.

It is known that VEGF promoter contains binding sites for STAT3. A recent study in mouse cerebral endothelial cells identified STAT3-mediated VEGF expression induced by ectopic decorin, a ligand for EGFR (Santra et al., 2008). The leptin promoter also contains two potential sites for STAT3 localized at -1715 and -1500 in the promoter. While it is known that STAT3 activation mediates many of the biological effects of leptin (Catalano et al., 2009), there are not evidences regarding STAT3 involvement in leptin gene transcription. Our study demonstrated for the first time that EGF-induced leptin and VEGF expression in colon cancer is mediated by and requires STAT3. Specifically, our results suggested that STAT3 binds both VEGF and leptin promoters under EGF stimulation in colon cancer cells and STAT3 down-regulation by RNA-interference significantly suppressed both VEGF and leptin expression.

Our previous study in cancer cells suggested that PI3K is involved in leptin expression (Bartella et al., 2008). PI3K involvement in leptin expression was also confirmed in other cell models (Cong et al., 2007; Tong et al., 2008). The PI3K/ $\mathrm{mTOR}$ pathway has also been shown to play an important role in VEGF regulation (Zhong et al., 2000; Laughner et al., 200 I; Kang et al., 2008). In agreement with these observations, we found that $\mathrm{PI}-3 \mathrm{~K}$ is required for leptin and VEGF expression under EGF treatment, especially for STAT3 recruitment to both VEGF and leptin promoters, as demonstrated by ChIP assay.

In summary, we demonstrated that in colorectal cancer cells, EGF can upregulate the expression of two pro-angiogenic factors, VEGF and leptin via the PI3K signaling pathway. We report that the mechanism of this EGF-activity occurs at transcriptional level and it is mediated by the recruitment of STAT3 on VEGF and leptin promoters. The fact that EGF can stimulate leptin expression in colon cancer suggest that leptin and its receptor can become novel pharmaceutical targets in colorectal cancer. In addition, STAT3, which appears to play a major role in regulation of genes involved in angiogenesis might serve as alternative target in colon cancer patients in which anti-EGFR therapies are not effective.

\section{Literature Cited}

Alvarez JV, Greulich H, Sellers WR, Meyerson M, Frank DA. 2006. Signal transducer and activator of transcription 3 is required for the oncogenic effects of non-small-cell lung cancer-associated mutations of the epidermal growth factor receptor. Cancer Res 66:3162-3168.

Amemori S, Ootani A, Aoki S, Fujise T, Shimoda R, Kakimoto T, Shiraishi R, Sakata Y, Tsunada S, Iwakiri R, Fujimoto K. 2007. Adipocytes and preadipocytes promote the proliferation of colon cancer cells in vitro. Am J Physiol Gastrointest Liver Physiol 292:G923-G929.

Anagnostoulis S, Karayiannakis AJ, Lambropoulou M, Efthimiadou A, Polychronidis A,

Simopoulos C. 2008. Human leptin induces angiogenesis in vivo. Cytokine 42:353-357.

Aparicio T, Guilmeau S, Goiot H, Tsocas A, Laigneau JP, Bado A, Sobhani I, Lehy T. 2004 Leptin reduces the development of the initial precancerous lesions induced by azoxymethane in the rat colonic mucosa. Gastroenterology 126:499-510.

Attoub S, Noe V, Pirola L, Bruyneel E, Chastre E, Mareel M, Wymann MP, Gespach C. 2000. Leptin promotes invasiveness of kidney and colonic epithelial cells via phosphoinositide 3-kinase-, rho-, and rac-dependent signaling pathways. FASEB J 14:2329-2338.

Bartella V, Cascio S, Fiorio E, Auriemma A, Russo A, Surmacz E. 2008. Insulin-dependent Bartella $V$, Cascio $S$, Fiorio E, Auriemma A, Russo A, Surmacz E. 2008.
leptin expression in breast cancer cells. Cancer Res 68:4919-4927.

Brenneisen P, Blaudschun R, Gille J, Schneider L, Hinrichs R, Wlaschek M, Eming S,

Scharffetter-Kochanek K. 2003. Essential role of an activator protein-2 (AP-2)/specificity 
protein I $(\mathrm{SpI})$ cluster in the UVB-mediated induction of the human vascular endothelial growth factor in $\mathrm{HaCaT}$ keratinocytes. Biochem J 369:34I-349.

Cao R, Brakenhielm E, Wahlestedt C, Thyberg J, Cao Y. 200I. Leptin induces vascular permeability and synergistically stimulates angiogenesis with FGF-2 and VEGF. Proc Natl Acad Sci USA 98:6390-6395.

Catalano S, Giordano C, Rizza P, Gu G, Barone I, Bonofiglio D, Giordano F, Malivindi R, Gaccione D, Lanzino M, De Amicis F, Ando S. 2009. Evidence that leptin through STAT and CREB signaling enhances cyclin DI expression and promotes human endometrial cance proliferation. J Cell Physiol 218:490-500.

Ciardiello F, Tortora G. 200I. A novel approach in the treatment of cancer: Targeting the epidermal growth factor receptor. Clin Cancer Res 7:2958-2970.

Cong L, Chen K, Li J, Gao P, Li Q, Mi S, Wu X, Zhao AZ. 2007. Regulation of adiponectin and leptin secretion and expression by insulin through a PI3K-PDE3B dependent mechanism in rat primary adipocytes. Biochem J 403:519-525.

Ferrara N, Kerbel RS. 2005. Angiogenesis as a therapeutic target. Nature 438:967-974.

Finkenzeller G, Sparacio A, Technau A, Marme D, Siemeister G. 1997. Sp I recognition sites in the proximal promoter of the human vascular endothelial growth factor gene are essentia for platelet-derived growth factor-induced gene expression. Oncogene 15:669-676.

Folkman J. 197I. Tumor angiogenesis: Therapeutic implications. N Engl J Med 285:1182-1186.

Frank DA. 2007. STAT3 as a central mediator of neoplastic cellular transformation. Cancer Lett 251:199-210.

Garofalo C, Koda M, Cascio S, Sulkowska M, Kanczuga-Koda L, Golaszewska J, Russo A, Sulkowski S, Surmacz E. 2006. Increased expression of leptin and the leptin receptor as a marker of breast cancer progression: Possible role of obesity-related stimuli. Clin Cancer Res 12:1447-1453.

Gonzalez RR, Cherfils S, Escobar M, Yoo JH, Carino C, Styer AK, Sullivan BT, Sakamoto $H$ Olawaiye A, Serikawa T, Lynch MP, Rueda BR. 2006. Leptin signaling promotes the growth of mammary tumors and increases the expression of vascular endothelial growth factor (VEGF) and its receptor type two (VEGF-R2). J Biol Chem 281:26320-26328.

Housa D, Housova J, Vernerova Z, Haluzik M. 2006. Adipocytokines and cancer. Physiol Res $55: 233-244$

affe T, Schwartz B. 2008. Leptin promotes motility and invasiveness in human colon cance cells by activating multiple signal-transduction pathways. Int J Cancer 123:2543-2556.

Kang J, Rychahou PG, Ishola TA, Mourot JM, Evers BM, Chung DH. 2008. N-myc is a nove regulator of PI3K-mediated VEGF expression in neuroblastoma. Oncogene 27:3999-4007. Klampfer L. 2008. The role of signal transducers and activators of transcription in colon cancer. Front Biosci 13:2888-2899.

Koda M, Sulkowska M, Kanczuga-Koda L, Cascio S, Colucci G, Russo A, Surmacz E, Sulkowski S. 2007. Expression of the obesity hormone leptin and its receptor correlates with hypoxia-inducible factor-I alpha in human colorectal cancer. Ann Oncol |8:vil| |6-vi|| 9 .

Laughner E, Taghavi P, Chiles K, Mahon PC, Semenza GL. 200I. HER2 (neu) signaling increases the rate of hypoxia-inducible factor Ialpha (HIF-Ialpha) synthesis: Novel mechanism for HIF-I-mediated vascular endothelial growth factor expression. Mol Cell Biol 21:3995-4004

Logan-Collins JM, Lowy AM, Robinson-Smith TM, Kumar S, Sussman JJ, James LE, Ahmad SA 2008. VEGF expression predicts survival in patients with peritoneal surface metastases from mucinous adenocarcinoma of the appendix and colon. Ann Surg Oncol 15:738-744.

Maity A, Pore N, Lee J, Solomon D, O'Rourke DM. 2000. Epidermal growth factor receptor transcriptionally up-regulates vascular endothelial growth factor expression in human glioblastoma cells via a pathway involving phosphatidylinositol $3^{\prime}$-kinase and distinct from that induced by hypoxia. Cancer Res 60:5879-5886.

Mason MM, He Y, Chen H, Quon MJ, Reitman M. 1998. Regulation of leptin promoter function by SPI, C/EBP, and a novel factor. Endocrinology I39:1013-1022.

Mendelsohn J, Baselga J. 2000. The EGF receptor family as targets for cancer therapy.

Oncogene 19:6550-6565.
Misztal-Dethloff B, Stepien H, Komorowski J. 2004. Effect of leptin on proliferative activity and vascular endothelial growth factor (VEGF) secretion from cultured endothelial cells $\mathrm{HECa} I 0$ in vitro. Endocr Regul 38:16I-166.

Niu G, Wright KL, Huang M, Song L, Haura E, Turkson J, Zhang S, Wang T, Sinibaldi D, Coppola D, Heller R, Ellis LM, Karras J, Bromberg J, Pardoll D, Jove R, Yu H. 2002. Constitutive Stat3 activity up-regulates VEGF expression and tumor angiogenesis. Oncogene 21:2000-2008.

Pore N, Liu S, Haas-Kogan DA, O'Rourke DM, Maity A. 2003. PTEN mutation and epiderma growth factor receptor activation regulate vascular endothelial growth factor (VEGF) mRNA expression in human glioblastoma cells by transactivating the proximal VEGF promoter. Cancer Res 63:236-24I.

Pore N, Jiang Z, Gupta A, Cerniglia G, Kao GD, Maity A. 2006. EGFR tyrosine kinase inhibitors decrease VEGF expression by both hypoxia-inducible factor (HIF)-I independent and HIF-I-dependent mechanisms. Cancer Res 66:3197-3204.

Santra M, Santra S, Zhang J, Chopp M. 2008. Ectopic decorin expression up-regulates VEGF expression in mouse cerebral endothelial cells via activation of the transcription factors SpI, HIFIalpha, and Stat3. J Neurochem I05:324-337.

Saxena NK, Sharma D, Ding X, Lin S, Marra F, Merlin D, Anania FA. 2007. Concomitant activation of the JAK/STAT, PI3K/AKT, and ERK signaling is involved in leptin-mediated promotion of invasion and migration of hepatocellular carcinoma cells. Cancer Res 67:2497-2507.

Seidel HM, Milocco LH, Lamb P, Darnell JE, Jr., Stein RB, Rosen J. 1995. Spacing of palindromic half sites as a determinant of selective STAT (signal transducers and activators of transcription) DNA binding and transcriptional activity, Proc Natl Acad Sci USA 92:304|-3045

Suganami E, Takagi H, Ohashi H, Suzuma K, Suzuma I, Oh H, Watanabe D, Ojima T, Suganami T, Fujio Y, Nakao K, Ogawa Y, Yoshimura N. 2004. Leptin stimulates ischemia-induced retinal neovascularization: Possible role of vascular endothelial growth factor expressed in retinal endothelial cells. Diabetes 53:2443-2448.

Tong KM, Shieh DC, Chen CP, Tzeng CY, Wang SP, Huang KC, Chiu YC, Fong YC, Tang CH 2008. Leptin induces IL-8 expression via leptin receptor, IRS-I, PI3K, Akt cascade and promotion of NF-kappaB/p300 binding in human synovial fibroblasts. Cell Signal 20:1478 1488.

Vigneron A, Gamelin E, Coqueret O. 2008. The EGFR-STAT3 oncogenic pathway upregulates the EmeI endonuclease to reduce DNA damage after topoisomerase I inhibition. Cancer Res 68:815-825.

Wauters M, Considine RV, Van Gaal LF. 2000. Human leptin: From an adipocyte hormone to an endocrine mediator. Eur J Endocrinol |43:293-3||.

Wei D, Le X, Zheng L, Wang L, Frey JA, Gao AC, Peng Z, Huang S, Xiong HQ, Abbruzzese JL, Xie K. 2003. Stat3 activation regulates the expression of vascular endothelial growth factor and human pancreatic cancer angiogenesis and metastasis. Oncogene 22:319-329.

Xiong H, Zhang ZG, Tian XQ, Sun DF, Liang QC, Zhang YJ, Lu R, Chen YX, Fang JY. 2008. Inhibition of JAKI, 2/STAT3 signaling induces apoptosis, cell cycle arrest, and reduces tumor cell invasion in colorectal cancer cells. Neoplasia 10:287-297.

Xu Q, Briggs J, Park S, Niu G, Kortylewski M, Zhang S, Gritsko T, Turkson J, Kay H, Semenza GL, Cheng JQ, Jove R, Yu H. 2005. Targeting Stat3 blocks both HIF-I and VEGF expression induced by multiple oncogenic growth signaling pathways. Oncogene 24:5552-5560.

Zafirellis K, Agrogiannis G, Zachaki A, Gravani K, Karameris A, Kombouras C. 2008. Prognostic significance of VEGF expression evaluated by quantitative immunohistochemical analysis in colorectal cancer. J Surg Res 147:99-107.

Zhong H, Chiles K, Feldser D, Laughner E, Hanrahan C, Georgescu MM, Simons JW, Semenz GL. 2000. Modulation of hypoxia-inducible factor Ialpha expression by the epidermal growth factor/phosphatidylinositol 3-kinase/PTEN/AKT/FRAP pathway in human prostate cancer cells: Implications for tumor angiogenesis and therapeutics. Cancer Res 60:154I-1545. 